\title{
EKSTRAK NIGELLA SATIVA L MENINGKATKAN EKSPRESI HNF-4A PADA TIKUS MODEL FIBROSIS HATI
}

\author{
Fathiyah Safithri
}

\author{
Fakultas Kedokteran, Universitas Muhammadiyah Malang, Jl. Bendungan Sutami 188 A Sumbersari malang, \\ Lowokwaru, Kota Malang, 65145, Indonesia, (0341) 582060
}

\begin{abstract}
Abstrak
Latar Belakang : Sirosis hati merupakan stadium akhir fibrosis hati. Pasien sirosis hati yang mengonsumsi N. sativa mengalami perbaikan berupa berkurangnya udem tungkai dan ascites serta peningkatan kadar albumin serum. Peningkatan kadar albumin serum mungkin disebabkan terjadi regenerasi hepatosit melalui diferensiasi sel punca endogen menjadi hepatoblas dengan markernya berupa HNF-4 $\alpha$ Tujuan penelitian : untuk membuktikan terjadi peningkatan ekspresi HNF- $4 \alpha$ setelah pemberian N. sativa pada tikus yang diinduksi CCl4 Metode penelitian : ekspreimental dengan rancangan a randomized post test only control group design, menggunakan 35 ekor tikus yang dibagi menjadi lima kelompok, normal, kontrol fibrosis hati dan fibrosis hati yang mendapat terapi N. sativa dengan 3 dosis berbeda. Induksi fibrosis hati dengan injeksi CCl4 1ml/kgBB i.p tiga kali/minggu selama 8 minggu. Setelah induksi CCl4, diberikan ekstrak N. sativa p.o 1,2; 2,4; 4,8 g/kgBB selama 4 minggu. Pada akhir penelitian, tikus dimatikan, organ hati diambil untuk diamati ekspresi HNF$4 \alpha$ dengan immunohistokimia. Hasil penelitian dan diskusi: Pemberian ekstrak $N$ sativa meningkatkan ekspresi HNF$4 \alpha(\mathrm{p}<0,001)$ dibandingkan dengan kelompok kontrol. Ekstrak $\mathrm{N}$ sativa memberikan pengaruh pada ekspresi $\mathrm{HNF}-4 \alpha$ $\left(\mathrm{p}<0,001 ; \mathrm{R}^{2}=81 \%\right)$. Kesimpulan : Ekstrak $N$ sativa dapat meningkatkan ekspresi HNF-4 $\alpha$ pada tikus model fibrosis hati
\end{abstract}

Kata kunci : Nigella sativa. liver fibrosis, ekspresi HNF-4 $\alpha$

\section{Pendahuluan}

Peningkatan kadar albumin serum disertai berkurangnya ascites dan udem tungkai bawah terjadi pada pasien sirosis hati yang mengonsumsi ekstrak jintan hitam (Nigella sativa) (Barakat, 2013). Sirosis hati merupakan fase akhir dari penyakit hati kronik, yang ditandai dengan akumulasi jaringan fibros berlebihan. Jaringan fibros terbentuk sebagai respon dari inflamasi kronik akibat jejas kronik hati yang menimbulkan kerusakan sel-sel hati. Kerusakan hepatosit dan adanya fibrosis menyebabkan penurunan sintesis albumin.

Berdasarkan data WHO, sirosis hati merupakan penyebab kematian peringkat ke delapan belas dengan jumlah kematian 800.000 kasus. (WHO, 2008). Secara umum diperkirakan angka insiden sirosis hati di rumah sakit seluruh Indonesia berkisar antara $0,6-14,5 \%$. dengan penyebab utama berupa virus hepatitis B (40-50\%) dan virus hepatitis C (3040\%) (Sudoyo, 2006). Data Riset Kesehatan Dasar (Riskesdas) 2013 melaporkan prevalensi hepatitis di Indonesia adalah $1,2 \%$, dua kali lebih tinggi dibanding tahun 2007. Data WHO (2008) melaporkan, sekitar 400 juta orang di dunia telah terinfeksi virus hepatitis $\mathrm{B}$, dan setelah 30 tahun kemudian 30\% pasien dengan hepatitis B kronik aktif akan berkembang menjadi sirosis hati, dan tanpa perawatan dalam lima tahun sekitar $15 \%$ pasien sirosis hati akan meninggal. Bila peningkatan kadar albumin serum pada pasien sirosis hati yang mengonsumsi jintan hitam dapat dijelaskan, maka diharapkan angka kematian akibat sirosis hati diturunkan.

Saat ini pendekatan terapi sirosis hati lebih banyak berdasarkan patogenesis penyakit, yaitu menghindari penyebab, mempercepat regresi fibrosis, dan mencegah komplikasi akibat sirosis hati. Terapi dengan pendekatan fisiogenesis, yaitu menginduksi sel sehat untuk menggantikan hepatosit yang rusak masih sangat terbatas. Salah satu bentuk terapi dengan pendekatan fisiogenesis ini adalah dengan aktivasi sel punca endogen. Dengan aktivasi sel punca diharapkan akan berdiferensiasi membentuk hepatosit baru yang menggantikan hepatosit yang rusak. Sel punca endogen teraktivasi ketika terjadi perubahan lingkungan mikro di sekitar sel punca tersebut sedemikian rupa sehingga sel punca terinduksi untuk berproliferasi, migrasi dan mencapai area jejas serta berdiferensiasi membentuk sel fungsional tertentu (Ma, 2014). Beberapa bahan alam (herbal) telah terbukti mampu mengubah lingkungan mikro sel punca dan mengaktivasi sel punca (Buhrmann, 2010; Sheng, 2013;Si, 2014; Zhao, 2015).

Jintan hitam sudah lama dikenal dan dipakai sebagai tanaman obat. Jintan hitam mengandung lebih dari 100 bioaktif (multiple compound) dan belum semua bioaktif diketahui aktifitasnya. Penelitian terdahulu tentang jintan hitam telah mengkaji potensinya sebagai protektor terhadap kerusakan jaringan dan potensi dalam regenerasi jaringan (Kanter, 2003; Albajali, 2011; Sariciceck, 2014). Berbagai jalur mekanisme $\mathrm{N}$ sativa telah ditemukan, namun sampai saat ini belum ada penelitian yang menganalisis keterkaitan kemampuan regenerasi $N$ sativa tersebut melalui jalur aktivasi sel punca endogen. Beberapa bioaktif berupa thymoquinone, asam oleat dan asam linoleat dalam penelitian terpisah masing-masing telah dibuktikan mampu mengaktivasi migrasi dan proliferasi sel punca endogen (Goessling, 2011 ; Smith, 2012). Diperkirakan bila bioaktif 
tersebut diberikan bersama-sama dalam bentuk ekstrak N.sativa akan memiliki kemampuan aktivasi sel punca endogen yang lebih besar dan bahkan dapat menginduksi hingga terjadi diferensiasi. Dari latar belakang tersebut, peneliti tertarik untuk meneliti apakah pemberian ekstrak $N$ sativa dapat menginduksi terjadinya diferensasi sel punca menjadi hepatoblas pada tikus model fibrosis hati di mana terbentuknya hepatoblas ditandai dari marker HNF-4 $\alpha$.

\section{Metode Penelitian}

Jenis peneltian yang digunakan adalah eksperimental dengan rancangan Post Test Control Group Design.Penelitian dilakukan di Laboratorium Farmakologi Fakultas Kedokteran Universitas Brawijaya Malang, selama 4 bulan, mulai bulan Maret s.d Juni 2016.

Populasi pada penelitian ini adalah tikus putih jantan (Rattus novergicus) strain wistar. Sampel yang digunakan adalah tikus dengan berat 180-200 gram dan berusia 2-3 bulan dalam kondisi sehat yang ditandai dengan gerakan yang aktif dan mata yang jernih. Randomisasi dilakukan dengan cara acak sederhana sesuai skema. Kriteria drop out adalah tikus yang sakit atau mati selama penelitian. Estimasi besar sampel berdasarkan penelitian Barlianto, 2011 menurut rumus Lwanga dan Lemeshow, 1999 adalah sebagai berikut:

$$
\begin{aligned}
& \mathrm{n}=\frac{2 \cdot \mathrm{s}^{2}\left(\mathrm{Z}_{1-\alpha / 2+} \mathrm{Z}_{1-\beta}\right)^{2}}{\left(\mu_{0}-\mu_{\alpha}\right)^{2}} \\
& \mathrm{n}=\frac{2 \cdot(32,5+16,92 / 2)^{2}(1,96+1,28)^{2}}{(146,50-102,33)^{2}}
\end{aligned}
$$$$
\mathrm{n}=6
$$

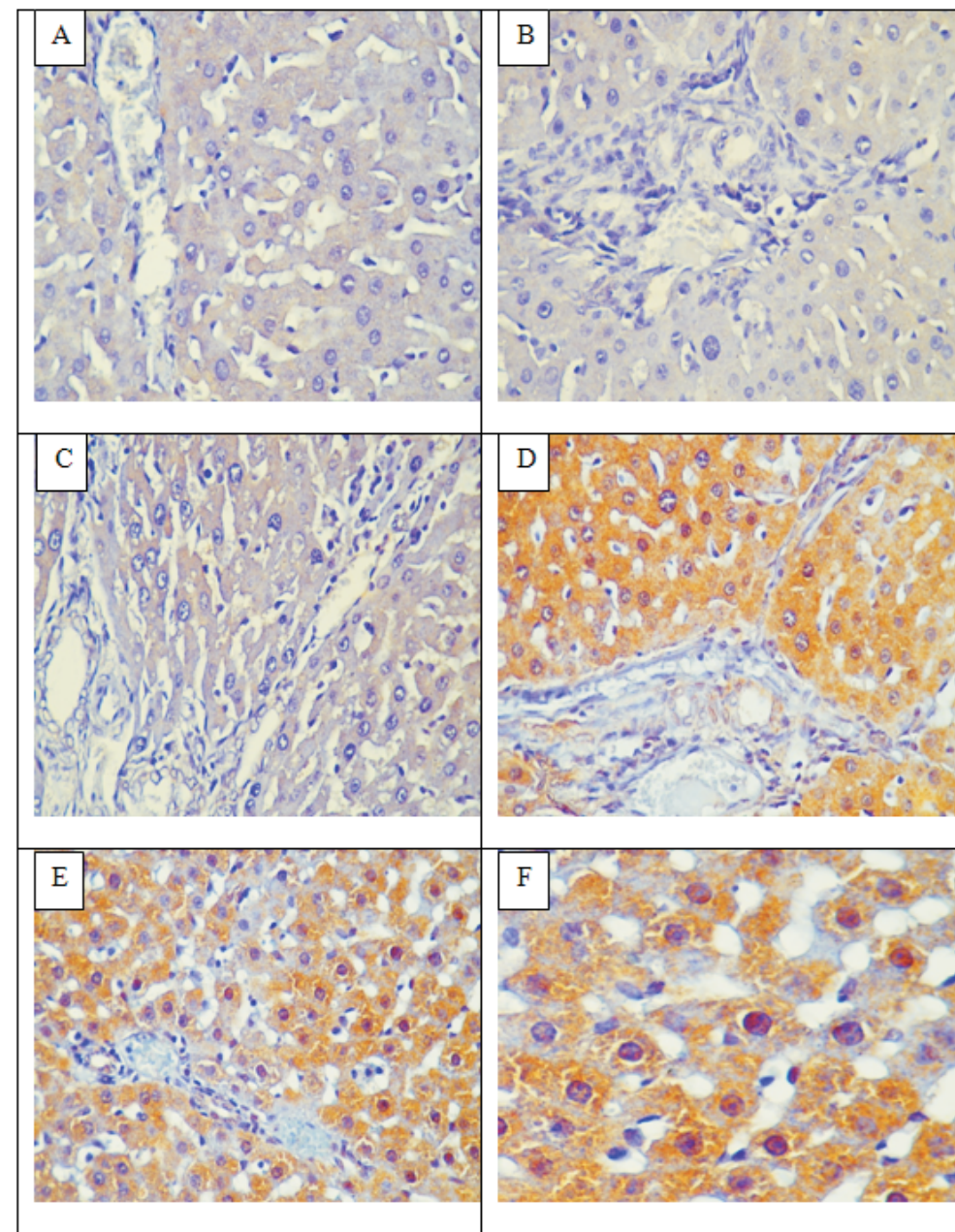

$\mathrm{n}=6$

Gambar. Ekspresi HNF-4 $\alpha$ pada hepatosit. Ekspresi positif HNF-4 $\alpha$ ditandai dengan warna coklat pada inti sel

hepatosit perbesaran $400 \mathrm{x}$

$$
\begin{aligned}
& \mathrm{n}^{\prime}=(1 / 1-\mathrm{f}) \times \mathrm{n} \\
& \mathrm{f}=10 \% \\
& \text { maka } \mathrm{n}^{\prime}=(1 / 0,9) \times 6=6,6
\end{aligned}
$$

Maka dalam penelitian ini menggunakan total replikasi sebesar 35 ekor tikus.

Seluruh sampel tikus dibagi menjadi lima kelompok, yaitu kelompok normal, kelompok kontrol (model fibrosis hati) dan 3 kelompok perlakuan. Induksi fibrosis hati dilakukan dengan injeksi CCl4 $1 \mathrm{ml} / \mathrm{kgBB}$ i.p tiga kali/ minggu selama 8 minggu (Amin, 2010). Kelompok perlakuan merupakan tikus model fibrosis hati yang mendapat terapi $N$. sativa p.o dengan 3 dosis berbeda, 1,2; 2,4; 4,8 g/kgBB selama 4 minggu (Barlianto, 2011; Saricicek, 2014). Setelah induksi CCl4, diberikan ekstrak N. sativa. Pada akhir penelitian, tikus dimatikan, organ hati diambil untuk diamati ekspresi HNF-4 $\alpha$ dengan immunohistokimia.

\section{Hasil penelitian}

Penelitian ini dilakukan dengan tujuan untuk mengetahui pengaruh pemberian ekstrak $\mathrm{N}$. sativa terhadap ekspresi HNF-4 $\alpha$ pada tikus model fibrosis hati yang diinduksi CCl4. Penelitian menggunakan total sampel 35 ekor tikus. Hingga akhir penelitian didapatkan 1 ekor tikus dari masing-masing kelompok mati, sehingga jumlah tikus per kelompok yang bisa dianalisis ada 6 ekor per kelompok. 
Data ekspresi HNF- $4 \alpha$ didapatkan dari pengamatan sel hepatoblas yang mengekspresikan $\mathrm{HNF}-4 \alpha$ pada pengecatan immunohistokimia kelompok normal, kelompok kontrol dan kelompok perlakuan. Ekspresi positif HNF- $4 \alpha$ ditandai dengan warna coklat pada inti sel hepatosit tersebut.

A. Kelompok tikus normal

B. Kelompok tikus fibrosis hati (kontrol)

C. Kelompok perlakuan 1 (dengan $N$ sativa $1,2 \mathrm{~g} / \mathrm{kgBB}$ )

D. Kelompok perlakuan 2 (dengan $N$ sativa $2,4 \mathrm{~g} / \mathrm{kgBB}$ )

E. Kelompok perlakuan 3 (dengan $N$ sativa $4,8 \mathrm{~g} / \mathrm{kgBB}$ )

F. Ekspresi HNF-4 á positif pada perbesaran 1000x

Hasil rerata dan simpang baku jumlah hepatosit yang mengekspresikan HNF-4 $\alpha$ pada kelompok normal, kontrol dan 3 kelompok perlakuan dapat dilihat pada tabel berikut ini :

\section{Tabel 3.1 Rerata dan simpang baku jumlah jumlah hepatosit yang mengekspresikan HNF-4 $\alpha$}

Hasil penelitian dianalisis menggunakan program SPSS versi 21. Hasil uji normalitas Saphiro-Wilk menunjukkan bahwa nilai p pada ekspresi HNF-4 $\alpha$ kelompok normal, kontrol dan perlakuan 1,2 dan 3 , berturut-turut adalah 0,$473 ; 0,110 ; 0,317 ; 0,012 ; 0,835$. Data di atas menunjukkan bahwa data ekspresi HNF-4 $\alpha$ kelompok P2, memiliki distribusi tidak normal $(\mathrm{p}<0,05)$ sehingga tidak memenuhi salah satu persyaratan uji parametrik.

Untuk menentukan signifikansi perbedaan rata-rata antar kelompok dengan variabel dependen ekspresi HNF-4 digunakan uji Kruskal Wallis. Hasil uji Kruskal Wallis menunjukkan nilai $\mathrm{p}($ ekspresi HNF-4 $\alpha)<0,001$, berarti terdapat perbedaan ekspresi HNF- $4 \alpha$, yang bermakna antara kelompok normal, kelompok kontrol dan kelompok perlakuan. Hasil uji korelasi Spearman menunjukkan terdapat hubungan antara dosis $N$ sativa dengan ekspresi HNF-4 $\alpha$ dengan nilai $r=0,936$, yang berarti mempunyai korelasi yang sangat kuat. Kekuatan hubungan tersebut bernilai positif artinya makin tinggi dosis, makin besar ekspresi HNF-4 $\alpha$. Hasil uji regresi menunjukkan bahwa dosis $N$ sativa memberikan pengaruh terhadap ekspresi HNF-4 $\alpha$ dengan $\mathrm{R}^{2}=81 \%$, yang mempunyai arti $81 \%$ ekspresi HNF-4 $\alpha$ ditentukan oleh dosis N. sativa, sedang $19 \%$ nya ditentukan oleh faktor lain.

\section{Pembahasan}

Penelitian ini telah membuktikan bahwa pemberian ekstrak $N$. sativa selama 4 minggu pada tikus yang telah diinduksi CCl4 selama 8 minggu menyebabkan peningkatan jumlah hepatoblas yang mengekspresikan HNF- $4 \alpha$.

$\mathrm{HNF} 4 \alpha$ merupakan salah satu anggota keluarga reseptor nuklear dari faktor transkripsi. HNF4á berperan penting dalam regulasi diferensiasi hepatosit dan regulasi fungsi hati, antara lain metabolisme energi, detoksifikasi xenobiotik, sintesis asam bilirubin dan produksi protein serum. HNF $4 \alpha$ juga penting dalam homeostasis lipid di hati, terbukti pada hati tikus yang mengalami defisiensi HNF- $4 \alpha$ terjadi perkembangan steatosis. Reseptor nuklear HNF- $4 \alpha$ merupakan regulator utama diferensiasi hepatosit selama perkembangan embrionik dan mempertahankan fenotip terdiferensiasi pada hepatosit dewasa. Penurunan regulasi HNF- $4 \alpha$ menyebabkan hilangnya fungsi hepatosit dan penurunan gen yang terkait dengan fenotip epitel. Penurunan ekspresi HNF4 $\alpha$ pada hepatosit matur menunjukkan terjadi progresifitas pertumbuhan tumor dan potensi metastasis. Peningkatan regulasi $\mathrm{HNF} 4 \alpha$ secara bermakna menghambat fibrosis hati dan sirosis pada tikus yang diinduksi dengan dietilnitrosamin. Ekspresi HNF-4 $\alpha$ yang berlebihan juga menghambat karsinogenesis dan metastasis (Bonzo, 2012).

Pada hati dewasa normal, HNF- $4 \alpha$ terekspresi pada nukleus hepatosit, namun tidak terekspresi pada sel kolangiosit. Diduga HNF-4 $\alpha$ tersebut berperan dalam diferensiasi progenitor menjadi hepatosit matur dan memelihara fenotip hepatosit matur. Pada hepatosit yang tersisa di area jaringan nekrotik tampak ekspresi HNF- $4 \alpha$ nya lemah pada sitoplasma. Ekspresi yang lemah menunjukkan bahwa fungsi hepatosit yang tersisa tersebut telah terganggu termasuk kemampuan regenerasi telah menurun. Ekspresi di sitoplasma menunjukkan telah terjadi gangguan lokalisasi nuklear yang mungkin terjadi pada bentuk immature sel duktular (sel oval). Pada hepatosit regeneratif, terjadi peningkatan ekspresi $\mathrm{HNF}-4 \alpha$ pada nukleusnya. HNF- $4 \alpha$ tidak terekspresi pada sel oval sampai sel oval tersebut berdiferensiasi hingga tahap akhir menjadi hepatosit matur (Hakoda, 2003).

Pada penelitian ini, ekspresi HNF- $4 \alpha$ meningkat pada fibrosis hati akibat induksi CCl4 menunjukkan hati masih mampu melakukan upaya regenerasi dan hati masih dalam kondisi terkompensasi (compensated liver). Ekspresi HNF-4 $\alpha$ turun secara bermakna pada keadaan gagal fungsi hati kronik tahap akhir (sirosis hepatis) (Nishikawa, 2015). HNF-4 $\alpha$ dapat mensupresi proses EMT (epithelial to mesenchymal transition) hepatosit dan meningkatkan ekspresi gen spesifik hati. Proses EMT hepatosit diinduksi oleh TGF-â1 melalui aktivasi snail transcripton factor dan jalur Smad2/3. Status EMT ditandai oleh peningkatan regulasi ekspresi mRNA kolagen tipe-1 dan deposisi kolagen tipe-1, hepatosit yang mengalami EMT secara substansial berubah menjadi populasi fibroblast- spesific protein-1 (FSP-1) (Yue, 2010). Penelitian oleh Fan, 2013 membuktikan bahwa pemberian $\mathrm{HNF}-4 \alpha$ pada tikus yang diinduksi thioacetamud dapat menyebabkan down-regulasi ekspresi gen profibrogenik, antara lain $\alpha$-SMA, TGF- $\alpha 1$, fibroblast specific protein-1 (FSP1), kolagen tipe 1 dan 3 . HNF $4 \alpha$ menyebabkan reverse sirosis hati tahap awal melalui hambatan pada jalur sinyaling ERK. Jalur ERK merupakan bagian penting dari jalur sinyal transduksi mitogen-activated protein kinase (MAPK), yang berperan potensial dalam fibrogenesis. Pada tikus model sirosis terjadi peningkatan MMP dan TIMP sehingga terjadi akumulasi ECM. Pemberian HNF- $4 \alpha$ dapat menyebabkan up-regulation MMP13 dan down-regulation TIMP-1, sehingga terjadi reverse fibrosis (Fan, 2013).

Pada penelitian ini, peningkatan ekspresi HNF-4 $\alpha$ setelah pemberian ekstrak jintan hitam (Nigella sativa) dosis $2,4 \mathrm{~g} / \mathrm{kg}$ BB peroral kemungkinan menunjukkan terjadi peningkatan diferensiasi dari sel punca mesenkimal atau dari sel progenitor hati menjadi hepatoblas.

Thymoquinone (TQ) sebagai bioaktif utama dari Nigella sativa kemungkinan berperan dalam diferensiasi sel punca / 
progenitor pada hepatogenesis. Penelitian invitro oleh Wirriestahun 2013 telah menunjukkan bahwa TQ berperan dalam diferensiasi sel progenitor pada osteogenesis. Sel osteoblas MC3T3-E1 diinduksi dengan thymoquinone (TQ) dan hasil analisis qRT-PCR menunjukkan bahwa TQ mempercepat diferensiasi osteoblas melalui peningkatan ekspresi gen untuk diferensiasi antara lain alkaline phosphatase, osteocalcin, dan osteopontin. TQ juga meningkatkan ekspresi bone morphogenetic protein-2 (BMP-2) dan regulasi fosforilasi jalur signaling ERK (Wirries, 2013).

\section{Kesimpulan dan Saran}

Berdasarkan hasil penelitian dan pembahasan di atas, maka dapat ditarik kesimpulan sebagai berikut :

1. Pemberian ekstrak jintam hitam (Nigella sativa) meningkatkan jumlah hepatosit yang mengekspresi ekspresi HNF-4 $\alpha$

2. Terdapat pengaruh pemberian ekstrak Nigella sativa terhadap ekspresi HNF-4 $\alpha$

3. Dosis ekstrak Nigella sativa yang paling optimal pada penelitian ini adalah sebesar $4,8 \mathrm{~g} / \mathrm{kgBB}$

\section{Saran pada penelitian ini adalah :}

1. Perlu penelitian lebih lanjut untuk meneliti mekanisme diferensiasi sel progenitor menjadi hepatoblas

2. Perlu penelitian lebih lanjut untuk meneliti peran peningkatan hepatoblas dalam memperbaiki kadar albumin serum

3. Perlu penelitian lebih lanjut tentang peran ekstrak Nigella sativa dalam diferensiasi sel punca / progenitor menjadi hepatoblas

\section{DAFTAR PUSTAKA}

Albajali AA, Nagi AH, Shahzad M, Ullah MI and Hussain S, 2011, Effect of Allium sativa L. on pancreatic $\alpha$ cells in comparison to Nigella sativa L. in streptozotocin induced diabetic rats, Journal of Medicinal Plants Research Vol. 5(24), pp. 5779-5784

Amin A, Kazem AH, Hassan SM, Youssef EA, Khalil EM, 2010, Effect of Silymarin on Liver Injury Induced by Carbon Tetrachloride in Rats: Histopathological and Immunohistochemical studies, Egypt. Journal of Experimental Biology (Zoology.), 6(1): 107 - 115

Barakat EMF, Wakeel LME, Hagag RS, 2013, Effects of Nigella sativa on outcome of hepatitis C in Egypt, World J Gastroenterol 28; 19(16): 2529-2536

120

Barlianto W, 2011, Modulasi Sistem imun dan Hambatan Airway Remodelling setelah pemberian Ekstrak Etanol Jinten Hitam (Nigella sativa) pada Mencit model Asma, disertasi, Universitas Brawijaya, Malang.

Bonzo AJ, Ferry CH, Matsubara T, Kim J, and Gonzalez FJ, 2012, Suppression of Hepatocyte Proliferation by Hepatocyte Nuclear Factor 4á in Adult Mice, The Journal Of Biological Chemistry Volume 287, No. 10, pp. $7345-7356$

Buhrmann C, Mobasheri A, Matis U and Shakibaei M, 2010, Curcumin mediated suppression of nuclear factor-êB promotes chondrogenic differentiation of mesenchymal stem cells in a high-density co-culture microenvironment, Arthritis Research \& Therapy, 12:R127

Fan TT, Hu PF, Wang J, Jiwei, Zhang Q, Ning BF, Yin C, Zhang X, Xie WF, Chen YX and Shi B, 2013, Regression effect of hepatocyte nuclear factor $4 \mathrm{a}$ on liver cirrhosis in rats, Journal of Digestive Diseases 14; 318-327

Goessling W, Allen RS, Guan X, Jin P, Uchida N, Dovey M, Harris JM, Metzger ME, Bonifacino AC,Stroncek D, Stegner J, Armant M, Schlaeger T, Tisdale JF, Zon LI, Donahue RE, North TE.Prostaglandin E2 enhances human cord blood stem cell xenotransplants and shows long-term safety in preclinical nonhuman primate transplant models. Cell Stem Cell. 2011; 8:445458. [PubMed: 21474107]

Hakoda T, Yamamoto K, Terada R, Okano N, Shimada N, Suzuki T, Mizuno M, and Shirator Y, 2003, A Crucial Role of Hepatocyte Nuclear Factor-4 Expression in the Differentiation of Human Ductular Hepatocytes, Laboratory Investigation Vol. 83, No. 10, p. 1395-1402

Kanter M, Meral I, Yener Z, Ozbek H, Demir H, 2003 Partial regeneration/proliferation of the beta-cells in the islets Of Langerhans by Nigella sativa L. in streptozotocin-induced diabetic rats. Tohoku J Exp Med 201(4):213-219.

Lwanga SK, Lemeshow S, 1999, Sample size determination in health studies, 1999, WHO versi 2.0, software version by KC Lun and Peter Chiam, National University of Singapore

Ma S, Xie N, Li W, Yuan B, Shi Y, dan Wang Y, 2014, Immunobiology of mesenchymal stem cells, Cell Death and Differentiation 21, 216-225

Nishikawa, et al, 2015, Resetting the transcription factor network reverses terminal chronic hepatic failure, The Journal of Clinnical Investigation.125(4):1533-1544.

Saricicek E, Tarakcioglub M, Saricicek V, Gulsen MT, Karakok M, Baltaci Y, Taysi S, 2014, Biomedical Research 25 (1): 32-38 ISSN 0970-938X

Sheng H, Rui X, Sheng C, Li W, Cheng X, Jhummon NP, Yu Y, Qu S, Zhang G, Qin L, 2013, A Novel Semisynthetic Molecule Icaritin Stimulates Osteogenic Differentiation and Inhibits Adipogenesis of Mesenchymal Stem Cells, International Journal of Medical Sciences, Vol. 10(6):782-789.

Si Y, Li Q, Xie C, Niu X, Xia X, and Yu C, 2014, Chinese herbs and their active ingredients for activating xue (blood) promote the proliferation and differentiation of neural stem cells and mesenchymal stem cells, Chinese Medicine, 9:13

Smith AN, Muffley LA, Bell AN, Numhom S, dan Hocking AM, 2012, Unsaturated fatty acids induce mesenchymal stem cells to increase secretion of angiogenic mediators, J Cell Physiol. 2012 September ; 227(9): 3225-3233.

Sudoyo AW, Setiyohadi B, Alwi I,Simadrata MK, Siti Nurdjanah. Sirosis Hati. Dalam ilmu penyakit dalam.Jilid I edisi IV. Jakarta.FKUI 2006: 668-73.

WHO., 2008. The Global Burden of Disease 2004. http:/ /www.who.int.

Wirries A, Schubert A, Zimmermann R, Jabari S, Ruchholtz S, El-Najjar N, 2013, Thymoquinone accelerates 
osteoblast differentiation and activates bone morphogenetic protein-2 and ERK pathway, International Immunopharmacology 15:381-387

Yue H-Y, Hou J-L, X Zeng, Chen Y-X, Zhong W, Hu PF, Deng X, Tan Y-X, Zhang J-P, Ning B-F, Shi J, Zhang X, Wang H-Y, Lin Y, Xie W-F, 2010, Hepatocyte nuclear factor $4 \mathrm{a}$ attenuates hepatic ?brosis in rats, Gut 59:236-246

Zhao B, Li H, Gao X, Ye Z, and Cheng S, 2015, The Herbal Compound "Diwu Yanggan" Modulates Liver Regeneration by Affecting the Hepatic Stem Cell Microenvironment in 2-Acetylaminofluorene/Partial Hepatectomy Rats, Evidence-Based Complementary and Alternative Medicine Volume 2015, Article ID 468303, 7 pages 